\title{
THE GREAT SHIFT: \\ THE RISE OF MEXICO AND THE DECLINE \\ OF PERU IN THE SPANISH AMERICAN COLONIAL EMPIRE, 1680-1809 *
}

HERBERT S. KLEIN

Columbia University

\section{RESUMEN}

A partir de la reconstrucción de las cuentas de la Real Tesorería para las tres principales colonias de Hispanoamérica desde el último cuarto del siglo xvir a la primera década del siglo XIX, este ensayo reconstruye el destino cambiante de los ingresos y gastos reales en estas cruciales economías americanas. Los vicerreinatos de Perú y México y la Audiencia de Charcos fueron las principales fuentes del superávit en las colonias americanas. Hasta 1700, las dos regiones andinas dominaron el sistema colonial hispanoamericano en términos de ingresos reales generados y de plata producida, para ser exportada a Europa. Sin embargo, estas regiones comenzaron a declinar en el siglo xvil. Los diferentes tipos de ingresos y gastos reales y su evolución son analizados para cada una de estas tres colonias a fin de determinar sus tendencias a largo plazo y su importancia relativa.

\section{ABSTRACT}

Using the reconstructed royal treasury records for the three principal colonies of Spanish America from the last quarter of the 17th century to the first decade of the 19th century, this essay constructs the changing fortunes of royal income and expenditures in these crucial American economies. The viceroyalties of Peru and Mexico and the Audiencia of Charcas were the principal sources of surplus revenues in the American colonies. Until 1700 the two Andean regions dominated the Spanish American colonial system in terms of generating royal income and in producing silver for export to Europe. But these soon declined relative to Mexico, which in the 18th century became the dominant economy and major source of royal income. The various royal revenues and expenditures and their performance over time are analyzed for all three colonies to determine the long term trends in their growth and relative importance.

* Revised version of a paper delivered at the «Coloquio Historia Económica: México-España en el Quinto Centenarion, México, 6.9 julio 1992. 


\section{INTRODUCTION}

From its discovery in the 1530 s to the last half of the 17 th century the viceroyalty of Peru - and the associated southern Andean region of the Audiencia of Charcas - were the dominant economic zone of the Spanish American economy, as reflected in mineral exports to Europe and royal treasury receipts. But by the 1660s the viceroyalty of Nueva España had begun to challenge Peru's leadership and by 1700 it took the lead in both indices. This shift of economic power from the Southern to the Northern Hemisphere of Spain's American empire is, of course, generally accepted in the traditional literature. But little attempt has been made to detail the timing or the profound transformations in the two regional economies which underlay this new balance of economic power. In the absence of all other comparable serial statistics for the colonial Spanish American economy, I will examine these changes in the late 17 th and 18th century American economy using royal treasury receipts in the three crucial colonial economies of Nueva España, Peru and the Audiencia of Charcas.

I have chosen to analyze the annual accounts of royal receipts and expenditures ', of the 48 local royal treasuries (caja real) which went to make up these three colonial regions, in the 130 year period 1680 to $1809^{2}$. I and others have already analyzed these complex royal treasury accounts for the Spanish empire 3 , and a formal methodology has been elaborated on how to handle most of the problems inherent in these annual income and expenditure materials ${ }^{4}$. Accepting all the limitations associated with these materials, one

1 The complete set of annual accounts for the Andean colonies are reprinted in TePaske and Klein (1982b) I (Peru); II (Upper Peru); and those for the cajas of Nueva Espana in Tepaske and Klein (1986, 1988).

2 Starting earlier than 1680 would have biased the results against Peru since there are major cajas such as Arequipa, Cailloma, Cuzco and Huancavelica which are missing annual accounts for most of the period up to 1680 . Also by the 1680 s it seemed as if both Mexico and the An. dean regions were recovering from the worst effects of the 17 th century crisis and still maintained their relative positions of importance from earlier in the century. After the political upheavals which began in 1810 , the treasury records no longer reflect local economic trends with the same accuracy as before.

${ }^{3}$ For detailed studies discussing the methodology and applying them to this material see Klein (1973), Klein (1985) and most recently Klein (1991). Similarly, one can also consult among his several articles those of TePaske (1982) and TePaske (1985) along with those cited in note 17, as well as our joint study on the 17th century crisis cited below. A survey of the work that has used this material is found in Klein and Barbier (1988) and most recently in Klein (1993) as well as TePaske (1991b).

${ }_{4}$ There were three major problems to resolve with these accounts. The first was to eliminate the most obvious instances of double counted funds from the income and expenditures sides of 
can still very fruitfully use these government generated data to get at long term economic trends as well as the relative economic health of each of the colonies. Although it would be ideal to deflate all numbers against price indices, no such systematic comparable price series exist for the colonial economies of the Andean regions and Mexico, thus all figures are given in current monies of account 5 . Equally, since a good part of this discussion is comparative, my conclusions will not be substantially revised once such series can be used.

That Peru was unquestionably Spain's primer colony in the 16th and 17th centuries is seen in the fact that between half to two thirds of total government silver exports to Spain or its colony in the Philippines, came from the Peruvian Viceroyalty until the decade of the 1660 s (see table 1) ${ }^{6}$. This dynamic growth of the Peruvian royal treasury was based on the extraordinary silver production of the mines Potosi in the allied Audiencia of Charcas (or Alto Perú/Bolivia). These high andean mines were the single most important source of silver in the Western World in the second half of the 16th and early 17 th century, and surpassed any other source of mineral production in America.

But the output of Potosi peaked in the 1590s (at a volume not achieved again until the late 19th century), and experienced a secular decline which did not end until the $1750 \mathrm{~s}^{7}$. Though smaller Andean mines initially compensated

the ledger. Total revenue in all the tables and graphs is defined as Gross Income or Expenditure less a series of uncollected income, double counted accounts and cash deposits of one kind or another. Thus total income revenues are gross income figures less Existencia del año anterior; Depósitos; Deudas para cobrar, and the Real Hacienda en Común category; while Total Expenditure figures also exludes depósitos, deudas para cobrar, specie or other government valued paper (papel sellado, bulas, etc.), as well as the reales labrados de barras. Secondly, given the missing years for many of the accounts, using an average decade estimate insures that the accidental factor of preservation will not distort the historical record. The use of averages to fill in the missing data tends to stress a greater stability in the income and expediture figures than if one were using the predicted numbers taken from a regression equation. On the other hand, given that the gaps in the data were often of several decades in length, generating the missing estimated values by using a regression equation would bias the accounts more than the use of an averaging equation. Finally, the pre-1709 accounts, and most especially those for the last quarter of the 17th century, had to be recalculated on a monthly basis (due to their being kept in multi-year formats) so that an annual, and therefore a decade estimate could be calculated.

s On this question of colonial price series see Klein and Engerman (1992). All figures are presented in the standard colonial currency of account, which was pesos $a 8$, or a peso valued at 8 reales. These colonial pesos were equal to 20 reales de vellón - which was the standard units used in metropolitan tax accounts. All pesos ensayados and pesos de oro have been converted into pesos a 8 .

6 Both the figures for surplus silver exports and for bullion production come from the royal treasury accounts themselves. The total bullion figures have been generated by TePaske from the mining and minting taxes registered in these accounts.

7 For the output of the Potosi mines, see Bakewell (1975), table I, 92-97; and Sierra (1808/1971). 
for the declines at Potosi, the long term trend was for Peruvian silver production to decline. Total silver output in the Peruvian viceroyalty and the Charcas audiencia peaked in the decade of the 1630s. Production thereafter declined in a slow but steady manner until the trough of the 1720 s. It was only in the 1790 s that combined Andean production finally surpassed the 1630 s figure (see graph 1).

\section{TABLE 1}

Estimate of Government Silver Shipped to Spain E Pbillipines from Peru and Mexico, 1591-1750, (in pesos a 8).

\begin{tabular}{|c|c|c|c|c|c|}
\hline \multirow{2}{*}{ Decade } & \multirow{2}{*}{$\begin{array}{l}\text { Remitted } \\
\text { from Peru }\end{array}$} & \multirow{2}{*}{$\begin{array}{c}\text { To Spain } \\
\text { from Mexico }\end{array}$} & \multirow{2}{*}{$\begin{array}{c}\text { To Pbilippines } \\
\text { from Mexico }\end{array}$} & \multicolumn{2}{|c|}{ Total remissions } \\
\hline & & & & $\%$ Peru & $\%$ Mexico \\
\hline $1591-99$ & $19,957,476$ & $9,333,073$ & 466,016 & 67 & 33 \\
\hline $1601-09$ & $17,249,406$ & $10,016,003$ & $1,174,782$ & 61 & 39 \\
\hline $1611-19 \ldots \ldots \ldots$ & $11,025,487$ & $6,072,134$ & $2,541,652$ & 56 & 44 \\
\hline $1621-29$ & $11,037,808$ & $5,782,816$ & $3,620,573$ & 54 & 46 \\
\hline 1631.39 & $16,577,813$ & $7,201,026$ & $3,672,874$ & 60 & 40 \\
\hline $1641-49 \ldots \ldots \ldots$ & $14,847,713$ & $2,981,421$ & $2,206,810$ & 74 & 26 \\
\hline $1651-59 \ldots \ldots \ldots$ & $10,812,749$ & $4,333,383$ & $1,508,388$ & 65 & 35 \\
\hline $1661-69$ & $2,973,745$ & $3,991,220$ & $1,379,509$ & 36 & 64 \\
\hline $1671-79$ & $2,089,103$ & $9,967,125$ & $1,628,439$ & 15 & 85 \\
\hline $1681-89 \ldots \ldots \ldots$ & 307,387 & $4,770,990$ & $1,952,190$ & 4 & 96 \\
\hline $1691-99 \ldots \ldots \ldots$ & 432,021 & $2,741,057$ & $1,661,385$ & 9 & 91 \\
\hline $1701-09$ & $1,658,007$ & $5,233,621$ & $1,248,873$ & 20 & 80 \\
\hline $1711-19 \ldots \ldots \ldots$ & 77,411 & $7,811,117$ & $1,010,868$ & 1 & 99 \\
\hline $1721-29 \ldots \ldots \ldots$ & $1,034,400$ & $5,586,811$ & $1,339,403$ & 13 & 87 \\
\hline $1731.39 \ldots \ldots \ldots$ & $1,427,272$ & $8,509,817$ & $1,510,826$ & 12 & 88 \\
\hline \multirow[t]{2}{*}{$1741-49 \ldots \ldots \ldots$} & 545,000 & $5,325,510$ & $1,761,649$ & 7 & 93 \\
\hline & $112,052,798$ & $99,657,124$ & $28,684,237$ & 47 & 53 \\
\hline
\end{tabular}

SOURCE: TePaske (1983), tables $1 \& 2$ a.

Mexican bullion production, which had grown slowly in the first half of the 17 th century, in contrast, took off in the 1670 s. In this decade its output finally passed total Andean production, and there began a long term secular growth which ended with Mexico producing over three times as much silver as the late 18th century Andean industry. 


\section{GRAPH 1}

Value of bullion production in Mexico, Peru \& Upper Peru, by decade, 1581-1810.

Millions of pesos a 8

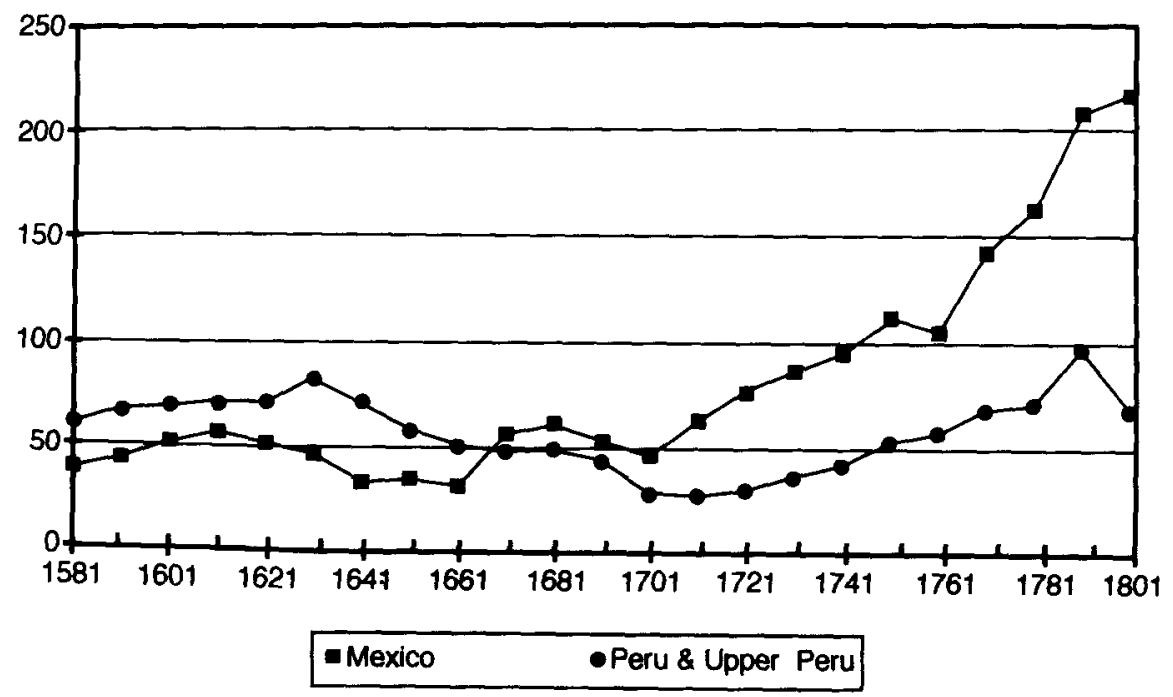

SOURCE: TePaske (1987), table 1.

Total royal revenues followed the path of silver production. The Crown saw its tax incomes from the two Andean regions seriously decline in the middle decades of the 17th century. This in turn led to a slower but still steady decline in surplus government funds generated. But surprisingly, long before Andean surpluses fell behind those registered from Mexico, Peru and Charcas stopped shipping funds to Europe. Thus as early as the 1660 s, long before total Mexican revenues surpassed those of the two Perus, Mexico had become Spain's dominant generator of surplus tax funds. What had happened is that the local American demands on Peruvian resources had suddenly escalated by the second half of the 17 th century as dependent zones such as Chile and the Rio de la Plata had become important regions of Spanish settlement. These treasuries were deficitory from the beginning and thus relied on Peruvian surpluses to support their settlement. Though the Andean treasuries were no longer serious suppliers of revenues to Spain, their role in the maintenance of American empire was crucial. 
Mexico became dominant in government silver exports to Europe by the 1660 s, but it was still the lesser economic zone as measured by total royal tax income. But the long term decline in bullion production in the Andes guaranteed that this Peruvian dominance would not continue. In fact, the first decade of the 18th century marks the definitive shift in total silver mine production and in royal revenue from Peru and Alto Perú to the Viceroyalty of New Spain (see graph 2).

\section{GRAPH 2}

\section{Total Royal Income in Mexico and the Two Perus, 1580-1809.}
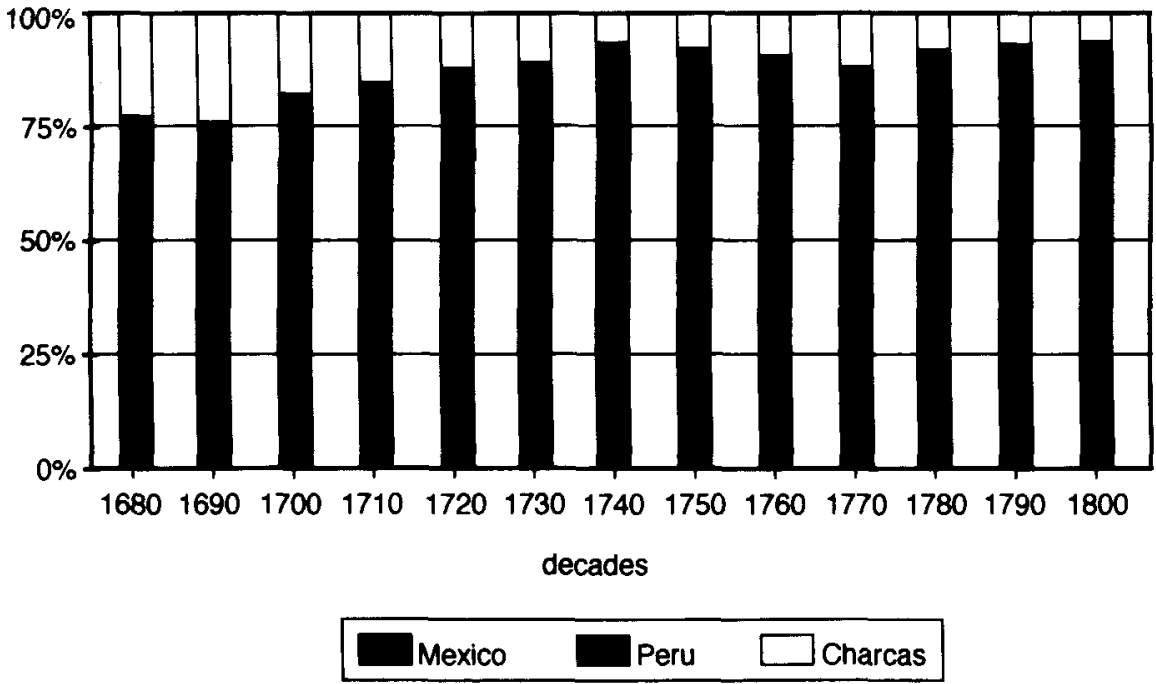

To analyze the relative economic growth of Mexico and the Andean centers, it is useful to break down that growth into its component parts. For this reason, I have combined the numerous tax categories into a few large groupings most closely related to local patterns of production and consumption ${ }^{8}$. These groups consist of taxes on mine production; taxes on local and interna-

8 This involved the regrouping of almost 6,000 individual taxes $(3,458$ income ramos and 2,456 expenditure ramos) into coherent groups of taxes. A list of the individual taxes which went to make up the income tax categories for Mexico can be found in Klein (1985) and Klein (1973), pp. $369-400$ 
tional trade (to which only Indian consumed goods were exempt); receipts from the sale of government monopoly products; and finally the head tax on Indian landowners and workers. These taxes explained over $90 \%$ of the income received in Charcas, and around half of the taxes in the two viceregal centers of Peru and Mexico.

\section{MINING}

The driving force behind the economies of both Mexico and the two Perus were the silver mines. These provided the bulk of the exports to Europe and generated the capital to import European goods. In turn the mining centers promoted the development of powerful regional markets to supply the basic necessities of the miners and their workers.

Although no detailed breakdown exists for the two Perus of the shares of the economy controlled by the various producers and markets, there does exist the estimate provided for Mexico by Humboldt at the end of the colonial period. Even at the height of the mining boom of Mexico, Humboldt estimated the annual value of mining at about 23 million pesos a 8 , compared to agriculture at 29 million pesos and manufacturing at between 7 and 8 million pesos 9 . Of these three pillars of the economy, agriculture, which employed most of the population and accounted for the majority of national output, was primarily directed toward internal trade and consumption, with only commercial dyes, some cotton, sugar, spices and condiments being exported to Europe (representing an average $20 \%$ of exports in peacetime). As for manufactures, this too was predominantly oriented to local market consumption, though Mexico did export to the rest of the Caribbean such royal monopoly products as gunpowder, finished jewelry and minted coins. In contrast, the mining industry was almost exclusively oriented toward exports, with its output of gold and silver accounting for $80 \%$ of the value of exports during any peacetime year ${ }^{10}$. So impressive was these silver exports in terms of quantity and value, that they accounted for $2 / 3$ of total world output, and guaranteed that New Spain had a consistently positive balance of trade ${ }^{11}$. It can be assumed that the two zones were roughly similar in the fact that agriculture was more important in terms of total value and of workers employed than the mining in-

\footnotetext{
${ }^{9}$ Humboldt (1811), III, 265, 347; IV. p. 290.

${ }_{10}$ Humboldt (1811), IV, pp. 362.363.

11 Humboldt (1811), III, p. 346.
} 
dustry, and that both were well ahead of manufacturing, which tended to consist of small units concentrated in production for the popular end of the market and with little ability to export beyond regional markets. Moreover, in the Andes as in Mexico, it was the mining industry which accounted for over three-quarters of the value of exports and paid for the bulk of imports of European textiles, manufactured goods and comestibles.

While mining played such a predominant role in international trade, it was less important in terms of generating income for royal taxation. Throughout most of the 18 th century, mining income made up only $20 \%$ to $27 \%$ of total royal revenues. But this was not a consistent pattern, as both in the $1680 \mathrm{~s}$ and in the $1780 \mathrm{~s}$ and afterwards, its relative importance dropped to half this amount. By the last fifth of the 18th century, in fact, taxes on trade, agriculture and commerce outdistanced mining in importance for the royal treasury. Evidently the Crown was unwilling to tax this industry too heavily, as studies of the Mexican industry showed. Humboldt estimated that the diezmo, cobo and minting taxes took only some $15 \%$ of the value of mine output, a figure which he claimed was lower than was then the norm for European miners ${ }^{12}$. Garner in his studies of individual Zacatecas mines estimated the rate at $12 \%$ for taxes and another $6 \%$ for royal mintage charges ${ }^{13}$.

Whereas the Mexican treasury receipts were much influenced by the mining taxes, those of the Peruvian viceroyalty were not a significant factor until well into the century. Representing only $1 \%$ of royal revenues in the 1680 s, Lower Peruvian mine taxes grew rather dramatically during the century despite the continued crises of the mercury mines of Huancavelica. The growth of Vico y Pasco was impressive and the receipts collected in other interior mines by the Lima treasury also were significant. Thus by the last decades of the century mine taxes were ranging from $10 \%$ to $16 \%$ of total royal receipts, and approximating the relative weight of such taxes in total Mexican income. Including the audiencia of Charcas, shows that mine income - which was always a much more significant part of total royal revenues here than elsewhere in the empire - did finally recover by the second half of the 18th century (see graph 3) ${ }^{14}$. That such royal revenues from mining taxes grew despite the halving of the tax rate early in the 18th century is impressive evidence for the im-

12 Humboldt (1811), IV, pp. 143-44.

13 Garner (1980), p. 177n.

14 These royal mine tax income figures follow closely the estimate provided by TePaske of estimated total mine production. The total Peruvian mine production of the two Perus began to grow after 1750 and by the 1790 s actually surpassed the peak 1630 s production figures. For the growth of Lower Peruvian mining in this period see Fisher (1977). 


\section{GRAPH 3}

Mine Income in Mexico and the Two Perus, 1680-1809.

\section{Millions of pesos a 8}

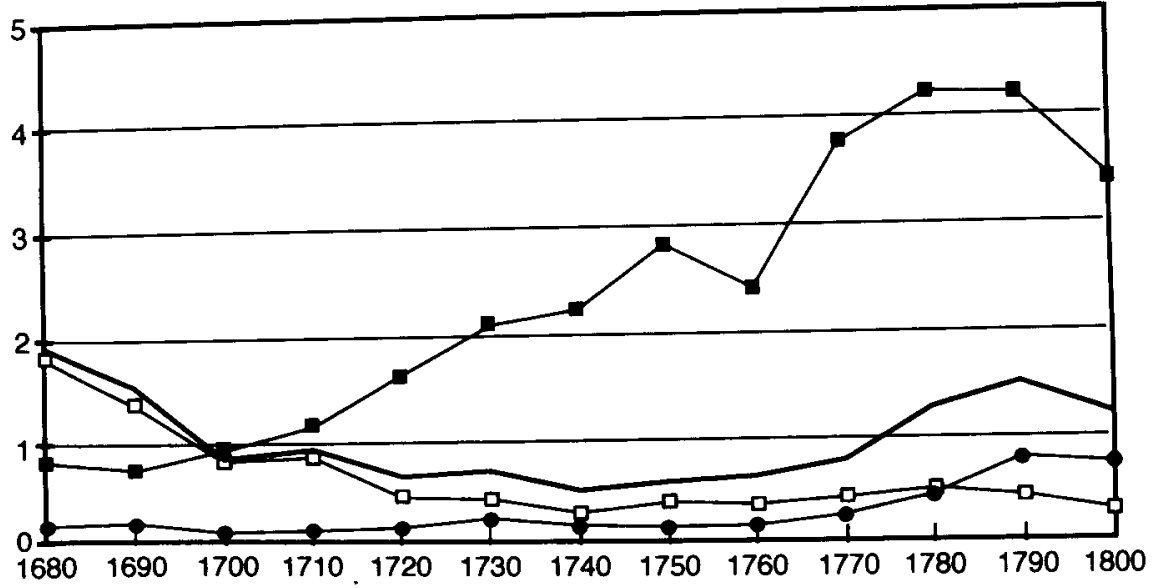

- Mexico - Peru a Charcas -Two Perus

portance of the small but dynamic element of the Lower Peruvian mining sector. But the fact that Peru and Charcas got tax relief much later than the Viceroyalty of New Spain ${ }^{15}$, goes a long way to explaining why the combined Andean treasuries produced more income from mine taxes until the first decade of the 18th century - some four decades after Mexican bullion production had surpassed the Andean output.

In contrast to the other two zones, mining tax revenues in the Audiencia of Charcas were the single most important source of government income until the last quarter of the 18 th century. Accounting for $2 / 3$ of all revenues at the end of the 17 th century, mine tax revenues continued to account for at least $40 \%$ to $50 \%$ of incomes until the 1760 s, but then dropped significantly as other tax incomes began to grow more rapidly. As with Peru, one of the fastest growing accounts was the tribute income which was to take the lead from mining and all other taxes by the last two decades of the century.

is Although the royal fifth had been reduced to a tenth of the value of total output in the Mexican mines by the middle of the 17 th century, such relief did not come to the Andean miners until 1736. Bakewell (1984), II, p. 134. 


\section{TRADE}

The category which most influenced total revenues after mining was taxes on trade and commerce. Trade, agricultural and commercial taxes tended to grow in quite close harmony with total revenues, at least until 1790 , for both Mexico and the two Perus. But revenues from trade and commerce taxes in Mexico already passed the combined total of Charcas and Peru by the 1690 s and continued to outdistance the two South American colonies for the rest of the 18 th century. Despite some impressive growth for the Andean colonies in the second half of the century, Mexico's growth was even more expressive, so that by the decade of the 1780 s it's trade revenues annually averaged 4.8 million pesos, or over four times as great as the 1 million annual estimate then registered for Charcas and Peru combined. Then in the 1790s, as mining tax revenues stagnated in Mexico, trade and commercial tax income in that viceroyalty definitively passed mine taxes and generated 1.2 million pesos more for the Crown than did mine income (see graph 4).

\section{GRAPH 4}

Trade income in Mexico and the Two Perus, 1680-1809.

Millions of pesos a 8

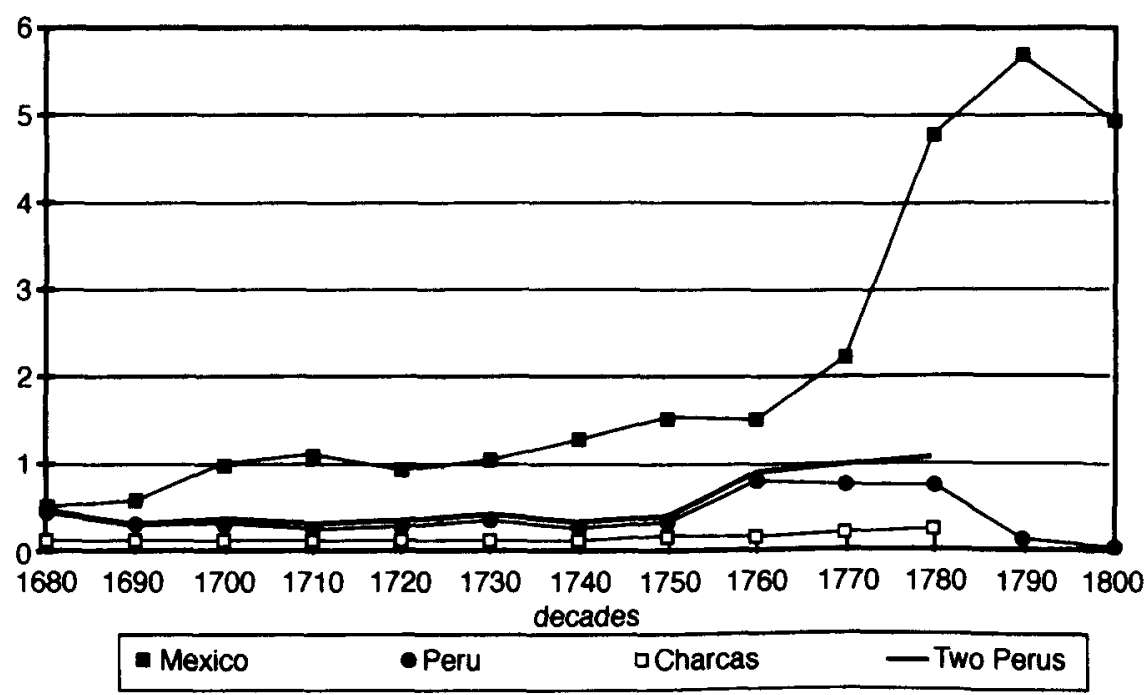

Notes: Trade for Charcas is missing for the last two decades. 
In contrast, trade receipts in Peru had always provided the single largest source of government income (or a third of total revenues at its height in the 1760 s), suddenly declined to last place as a source of revenue among the principal components of taxed income in Peru after the wars of empire began to seriously disrupt international trade in the 1790s. Thus well before the end of the colonial period, Peruvian trade was undergoing a serious crisis, at the same time as local mining receipts continued to expand. In contrast to Mexico both mining and tribute taxes (in the 1780s) had surpassed trade taxes in importance.

As for Alto Peru, trade and commerce taxes were a small share of total income but varied little in their relative importance throughout the period (see graph 4). Consistently averaging between $5-10 \%$ of total revenues, commercial and trade tax revenues tended to move in close association with total revenues. A significant growth in those trade revenues thus occurred at mid century and actually doubles from the 1760s to the 1770s. Though Alto Peru probably suffered from the crisis in trade which affected Lima in the post 1790 period, the lack of relevant data from the Potosi materials makes it impossible to estimate how the international trade crisis affected royal receipts in Charcas.

\section{MONOPOLY}

Monopoly tax revenues also showed important differences between the three colonies. The range of products which were either taxed as monopolies or were government products was amazing, going from the standard European monopoly items such as stamped official paper and playing cards to cockfights, snow and gunpowder. But the most important monopolies in terms of generating income were the sale of mercury to the silver miners, and liquor and tobacco sales to the general public. Though varying from region to region, there is little doubt that mercury sales were the single largest generator of income in Charcas and Mexico, though less so in Peru. In all regions liquor sales were important, and the tobacco monopoly was of such an importance, that in the second half of the 18 th century it formed a separate monopoly with its own accounting system independent of the royal treasury.

The movement of monopoly consumption income in Mexico closely paralleled that of gross revenues (see graph 5). There was little growth until the 1730 s, when suddenly such taxes passed the million peso mark. Growth was impressive for the rest of the century and ended up at over 5 million pesos per 


\section{GRAPH 5}

Monopoly Income in Mexico and the Two Perus, 1680-1809.

Millions of pesos a 8

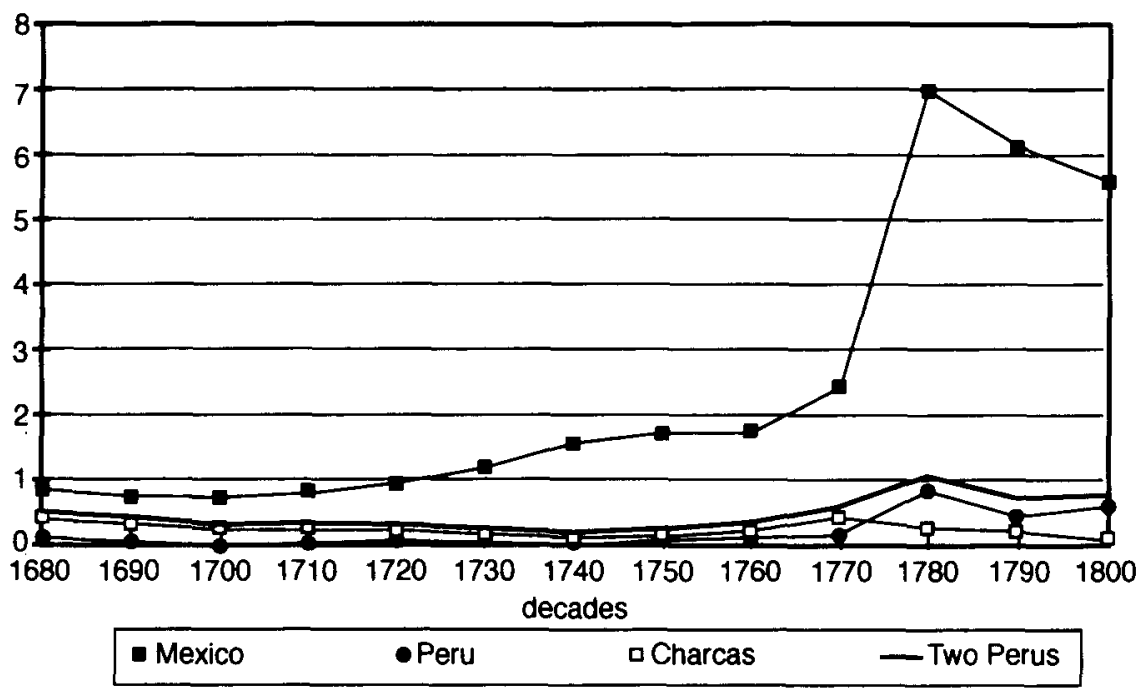

annum by the end of the century, having passed mining taxes in importance by the 1780 s and more or less keeping pace with trade incomes ${ }^{16}$.

Within each treasury district in New Spain the mix of incomes was quite different. Overall traditional estancos accounted for about half of all monopoly incomes, mercury about $30 \%$ and liquor sales about $20 \%$, though the mix would vary considerably between mining and non-mining districts. What is most interesting, however, is the steady and almost universal nature of monopoly incomes. In all but four of the 23 Mexican treasuries monopoly consumption taxes provided important and steady royal incomes. Thus along with commercial and trade taxes, monopoly consumption taxes were the most widely distributed taxes in the viceroyalty.

16 While I have listed 6.2 millions pesos as the total average monopoly income per annum in the decade of the 1780 s for monopoly consumption receipts, this number should be treated with caution. Some 1.1 million pesos of this total is accounted for by two exceptional year listings for mercury receipts in the port of Veracruz, which in all its history only had such receipts for a total of five years, and in the other 3 years was of insignificant amounts. These million totals in two years are extraordinary incomes which may in fact be double counted receipts from other treasuries. 
In the Peruvian situation, monopoly taxes grew at a pace consistent with total revenues, and on average accounted for $7 \%$ of total revenues. Only in. the 1770 s and 1780 s did monopoly revenues outpace the growth in total income, but then they fell back to an earlier rhythm at the end of the period. As was to be expected, the mining centers were important in mercury sales, while Lima alone accounted for half of all incomes and participated in all types of monopoly revenues.

In the case of Alto Peru monopoly incomes fell less rapidly than did total revenues and thus tended to increase their share of total revenues, rising by the 1720 s to $25 \%$ of total incomes. But then their growth slowed considerably as total revenues expanded. In contrast to Peruvian developments, however, mercury income in Charcas was overwhelmingly the predominant producer of monopoly incomes, and thus mining and monopoly tax revenues tended to move closely together, especially in the second half of the 18 th century.

\section{TRIBUTE}

Since the tribute taxes on Indian heads of households were relatively fixed, being based on initial assessments of the value of the land held in each free Indian community, growth and decline in tribute income tended to reflect the natural growth of the Indian population. Thus tax income generated by this discriminatory head tax followed very general economic trends which were also reflected in population expansion or contraction (see graph 6).

Unlike the other major taxes so far examined, the tribute tax was much more highly concentrated in each of the colonies, since it was exclusively linked to a clearly defined rural population living in free communities. By the end of the 17th century, for example, the regions in the northern part of the Viceroyalty of New Spain were primarily populated with mestizos and landless and non-community Indian. They therefore paid little in the way of tribute taxes. In contrast the central and southern zones, the old core area of the Aztec empire, contained the majority of the settled Indian peasant communities and thus provided the bulk of royal tribute monies.

The surprising sensitivity of the Indian population and its growth to general economic trends is well revealed in the high correlation between tribute income and total revenues. Until the 1780s, Indian tribute monies in New Spain averaged within a very short range of from $5 \%$ to $8 \%$ of total income. However, the tribute tax proved immune to the crises in international trade and regional mine production, and continued to grow until the Hidalgo rebellion of 1810 . 


\section{GRAPH 6}

Tribute Income in Mexico, and the Two Perus, 1680-1809.

Thousands of pesos a 8

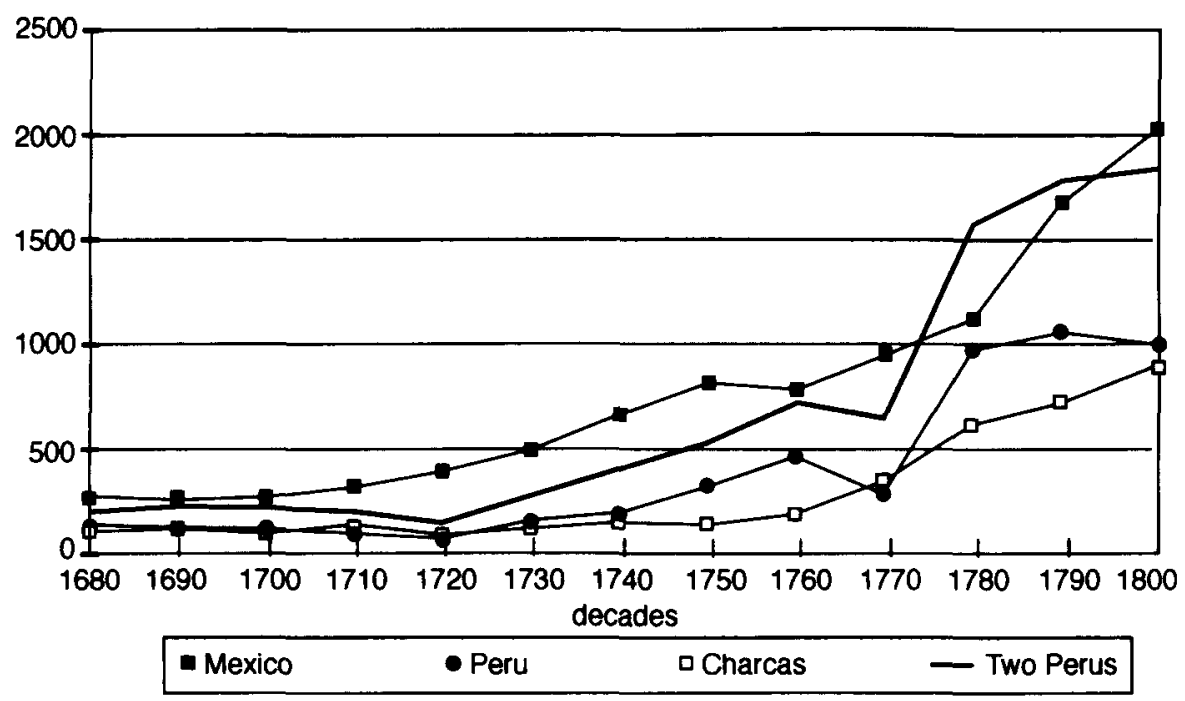

Tribute taxes, were also highly unevenly distributed in the Peruvian situation. Lima in this case produced on average only $18 \%$ of total revenues whereas such southern highland centers as Puno and Cuzco accounted for almost half of all income. In contrast to all other revenues, tribute income declined less in the initial decades after the 1680s, and though experiencing an usual decline in the 1720 s, it recovered quickly and then went on to increase at a steady pace. So dramatic was this growth that tribute was almost ten times greater in the $1790 \mathrm{~s}$ than in $1680 \mathrm{~s}$. By the $1780 \mathrm{~s}$ it became the single largest source of royal revenues - a position it maintained to the end of this period.

In this as in so many other areas, Alto Peru followed a path similar to that of the Peruvian viceroyalty. In contrast to the other two regions, however, tribute revenues were more evenly distributed and were an important aspect of all local treasury incomes. Charcas, like Peru, also experienced an unusual and sharp drop in tribute revenues in the 1720 s - clearly reflecting a pan-Andean crisis in the Indian peasant communities- but otherwise experienced relatively steady growth throughout the period. This growth meant that tribute income by the 1790 s had even passed mining income and was the audiencia's largest single source of government income (see graph 6). 


\section{SPECIAL WAR TAXES AND THE POST-1790 «BOOM»}

The changes in the post-1790 period, especially in total Mexican receipts, deserves greater explanation because of its controversial and special nature. Most of this growth came from the previously insignificant tax category of loans. In the late 18 th century these prestimos rose to prominence in the total picture of royal revenues in the viceroyalty of New Spain. Forced and voluntary loans and other special emergency taxes were used to support a debt ridden and increasingly bankrupt imperial treasury incapable of prosecuting a series of late 18th century international wars on the basis of normal tax revenues ${ }^{17}$. With the onset of almost continuous warfare beginning in 1793 , these special loans and exactions become the single most important source of revenues from Mexico, if not from the Andean treasuries, though no zone escaped these exactions. Clearly not all of these forced loans were fully collected, but there is little question that they fell heavily on the American populations.

For Mexico, these new taxes caused a fundamental shift in the basis of royal tax incomes. Production, trade, consumption and tribute revenues which had formed the basis of royal income prior to 1780 , were replaced by loans and new miscellaneous special taxes after that date, as the single largest source of income. What the costs of these exploitative taxes on private capital accumulation were, is difficult to assess. But in Mexico and Peru they came at the same time as an international trade crisis caused by the war, which blocked off traditional incomes and foreign capital investments. This combined with the scarcity of mercury imports, meant that mining halted in many Andean and Mexican zones even before the outbreak of fighting in the wars of independence in the first quarter of the 19th century.

In the case of Peru, some special subsidies and war taxes existed, but clearly the economy could not support the type of capital extraction that the Crown developed in Mexico. In fact such taxes produced little revenue and such miscellaneous incomes had little impact in increasing overall revenues. For this reason, such basic taxes as those on tribute, monopolies and mining income actually increased their relative rates of participation in the last three decades of the period.

17 An excellent review of these special taxes, forced loans and patriotic gifts which drained capital from Mexico is found in Marichal (1990). Also see Pérez Herrero (1980). Finally the impact of the international wars and internal early 19 th century rebellions on regular fiscal collec. tions has been examined by TePaske (1991a), and his analysis of the two principal regional cajas in the late colonial period is contained in TePaske (1986). 
Alto Peru also was not used by the Crown as a source of new funds in the post 1780 period. There were the special war taxes and as many new censos as could be found in Peru, but like Peru these added only small amounts to the income ledger and did not change the relative weight of the other major sources income. Thus the experience of both Perus would seem to suggest that the Crown concentrated all of its special energies on its richest colony and made no serious attempt to extract extra resources from its weaker colonial American possessions.

\section{GENERAL TRENDS IN EXPENDITURES}

A look at the long term movements in expenditures shows two clearly defined patterns. The first and most obvious is that total expenditures moved closely with total income figures in terms of growth and decline over this 130 year period. In all regions there was consistently a high and significant correla-

\section{GRAPH 7}

Total Expenditures in Mexico and the Two Perus, 1680-1809.

Millions of pesos a 8

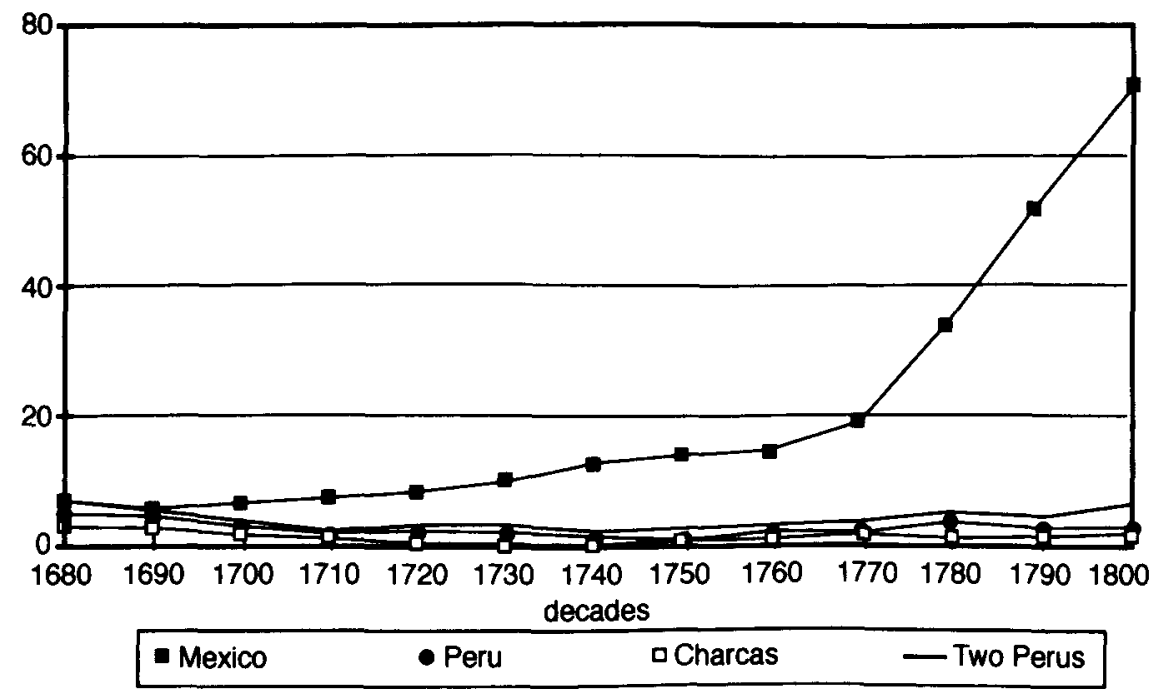


tion between the movement in income and resulting expenditures ${ }^{18}$. Obviously, the Crown spent only what it had and if that income disappeared it did not «invent» new incomes or go wildly into deficit financing. Thus when income declined drastically, so too did expenditures in quite close correlation.

Secondly, it is evident that expenditures never fell below income growth rates in New Spain, though they certainly did so in both Perus. It would appear that the Crown had more of an expectation of growth or that it was more willing to gamble with accumulated debt in New Spain than it was in the Perus. This could mean that it really anticipated long term growth in New Spain, as opposed to an expectation of long term decline in the Perus.

Examining the major components of expenditures in the three treasuries we find some marked differences. In Mexico and Peru war related expenditures for army and naval affairs were the single most important item of governament concern (see graph 8). In Mexico such expenses varied considerably but

\section{GRAPH 8}

War Expenditures in Mexico and the Two Perus, 1680-1809.

Millions of pesos a 8

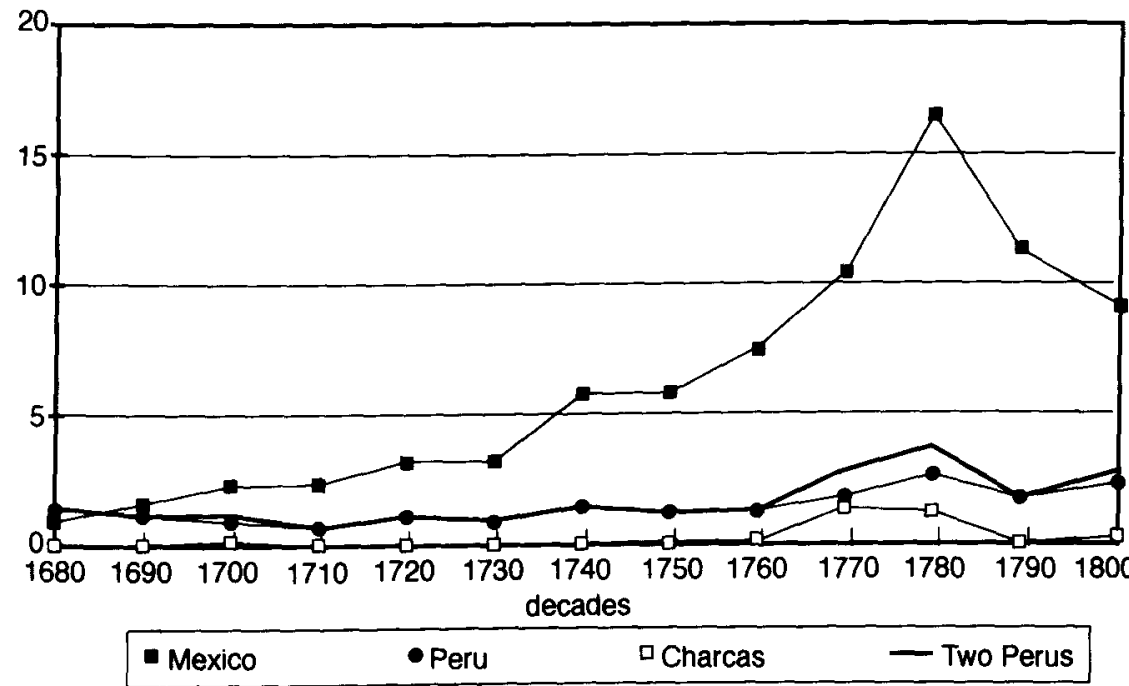

18 All the correlations I have run between gross income and gross expediture on an annual basis - which is how Crown would have perceived its revenues - was both significant and very highly correlated - being on average over 95 for all major treasuries. 
on the whole averaged just under half of all expenditures, going from a low of $22 \%$ in the 1760 s to a high of $47 \%$ in the 1780 s.

In contrast the essentially interior colony of Alto Peru devoted few of its tax resources for local military expenditures. On average it spent only about a tenth of its revenues on local military affairs except in the crucial period of the Tupac Amaru rebellions, when such expenditures absorbed as much as $48 \%$ of total expenditures.

Both Peru and Mexico spent little on administration -Peru being a bit more costly with about $15 \%$ of its budgetary expenses going in this category while Mexico only averaged some 5\%. But Alto Peru averaged over $30 \%$ for such expenses overall, and such administrative costs only began to fall to the Mexican levels in the last quarter of the century. Thus the total level of spending on administration in the two Perus, was considerably higher than in Mexico (see graph 9). This finding is difficult to explain. Mexico was the more populous and richer zone, with as wide an administrative coverage from the geographic point of view as the two Perus, yet it expended less total funds in absolute terms on administration until the 1750s than either of the other two

\section{GRAPH 9}

Administration Expenditures in Mexico and the Two Perus, 1680-1809.

Millons of pesos a 8

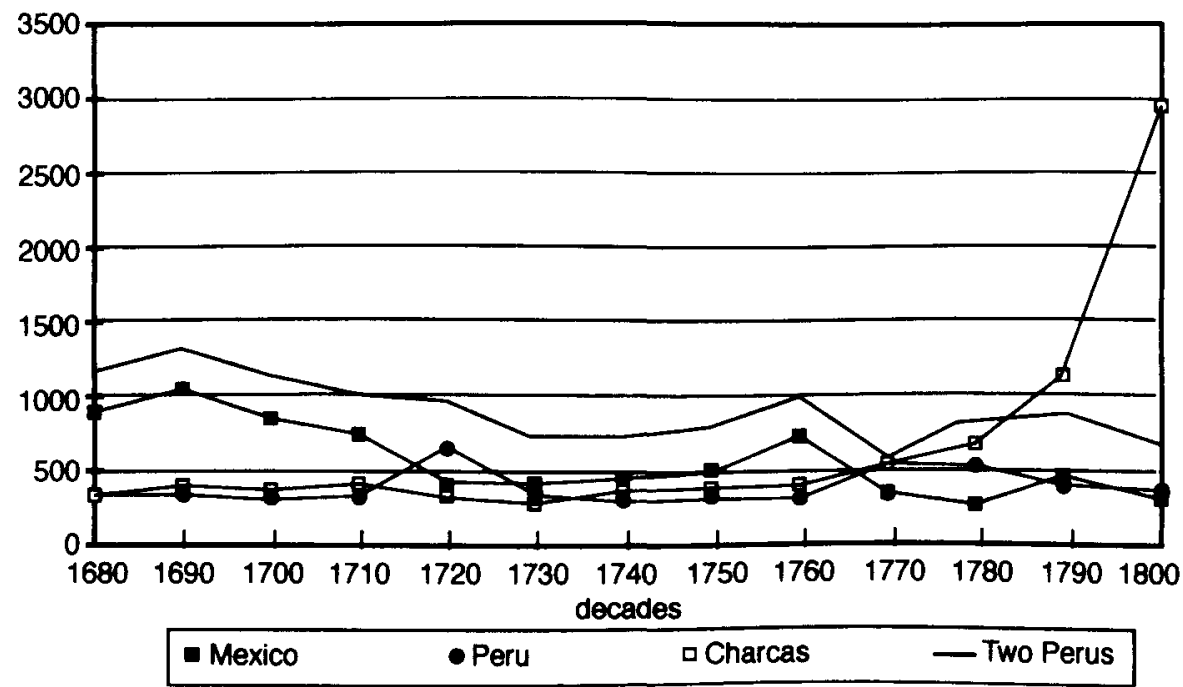


colonies. Moreover, its administrative expenses only surpassed the combined Peruvian costs in the 1790 s. Does this mean that the Mexican operation was a more efficient one and better administrated than the two Perus? This would seem to be the conclusion from examining graph 9 .

The surplus revenues category in all three regions well reflects the varying fortunes of the local economy (see graph 10). The ability of New Spain to send large sums of specie to Spain and the Philippines throughout the period, contrasts sharply with inability of Lima to produce excess revenues after $1750^{19}$. In contrast, Charcas was able to supply both an important subsidy to Lima (not reflected in the figures in graph 10) until the 1710s, which had peaked at half a million pesos in the $1680 \mathrm{~s}$, as well as maintain a steady supply of excess funds for the deficitory operations in the Río de la Plata. These Buenos Aires subsidies, known as the situado, tended to reflect the highs and lows of alto-

\section{GRAPH 10}

Remittances and Subsidies from Mexico and the Two Perus, 1680-1809.

\section{Millons of pesos a 8}

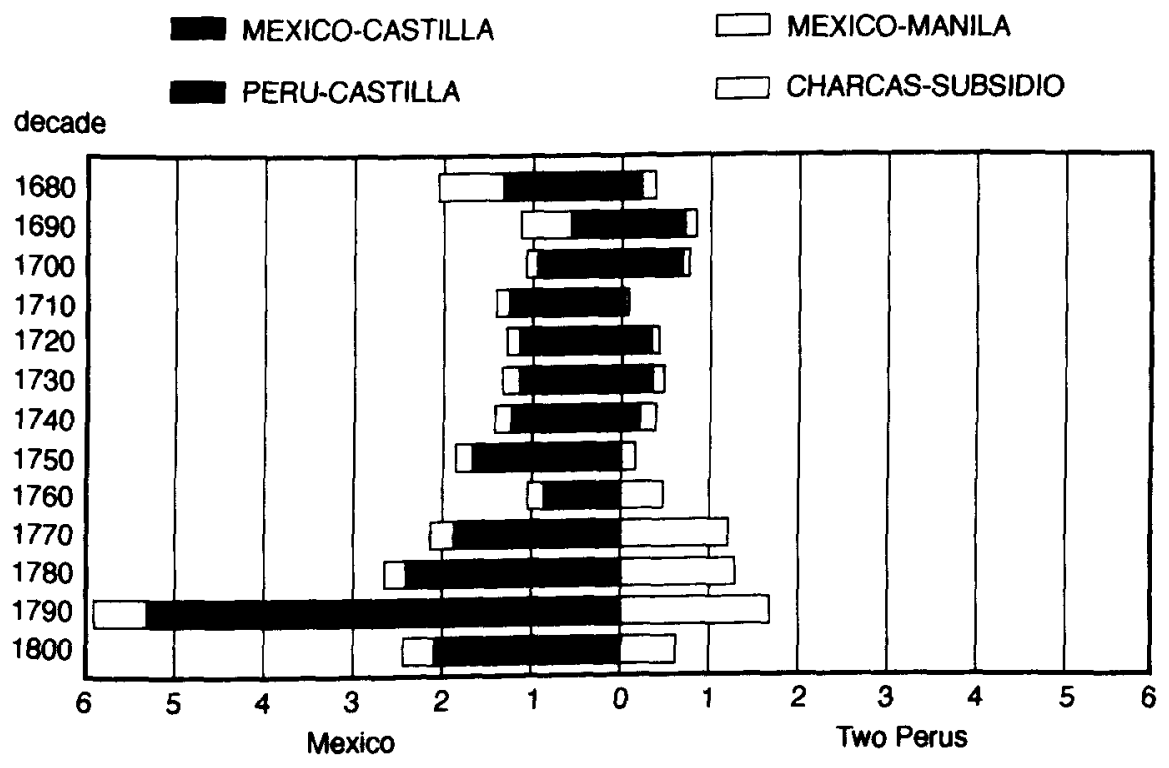

19 For a survey of the situado sent to the Philippines see, Bauzon (1970). 
peruvian royal income. Thus they dropped to dramatically low levels in the middle decades of the century and then rose again as mining production and the general economy boomed at the end of the colonial period. Reaching almost 1.7 million pesos in the 1790s, such excess funds shipped from Charcas was the single most important source of government revenues for the Buenos Aires viceroyalty.

\section{CONCLUSION}

Before analyzing the final results of these calculations in royal income and expenditures in these three colonies some modest disclaimers are worth noting. The changes in taxation in the 1730s (the incorporation of new categories of Indians subject to tribute and the halving of the basic mine tax in the Andean colonies) did temporarily generate new funds beyond the normal growth of the economy being taxed. It is also probable that ongoing changes in tax procedures such as expansion of the tax base, changes in rates or in exclusions, may have suddenly changed tax receipts in a given local environment ${ }^{20}$. But overall receipts - with the exception of the emergency taxes in Mexico at the end of the 18th century - followed basic changes in the economy over the long period. Also the fact that royal expenditures were so highly correlated with income trends meant that the Crown obviously responded in a reasonably rational economic way to declines in revenues, by severely reducing expenditures - rather than by any imaginary deficitory financing.

Accepting then that tax flows did reflect basic changes in the economy, the question is what these flows tell us about the history of the Spanish American economy in the period 1680-1809. Some very broad patterns are apparent. There was obviously a late 17 th century period of growth, followed by an early 18th century period of intense depression ${ }^{21}$. Evidently the Mexican economy was only temporary slowed by this crisis, whereas for both Perus it was a crisis of such profound proportions that recovery was only moderate (see table 2). It would seem that the fundamental decline of Potosi mining put severe strains

20 It is quite conceivable, as O'Phelan has recently argued that some of the increase in royal revenues in the second half of the 18th century may be due to the expansion of the tax base itself and the inclusion of Indians and other previously exempt groups. See O'Phelan Godoy (1986).

21 For more details on the 17 th century crisis as seen from these fiscal accounts see TePaske and Klein (1981), and a «Rejoinder» to the critiques of Israel and Kamen, TePaske and Klein (1982a), pp. 157.162. 
on both Peruvian economies. The further blow of the withdrawal of Alto Peruvian funds and their transfer to Buenos Aires - along with an eventual political union in the 1770 s, meant that the economy based on Lima and its associated zones never really recovered its 17 th century position of leadership. The recovery of Alto Peruvian mining through government subsidies and recovery of new deposits in Oruro and other zones guaranteed that by mid century Alto Peru would once again begin to grow at a more than reasonable rate. Peru also experienced a late 18th century growth in mining output, but together these new developments still did not match the spectacular growth of the northern viceroyalty.

TABLE 2

Index of Growth of Total Income in Three Regions $(1680-89=100)$

\begin{tabular}{|c|c|c|c|c|c|}
\hline Decade & Mexico & Peru & Charcas & $\begin{array}{l}\text { Two } \\
\text { Perus }\end{array}$ & $\begin{array}{c}\text { All Three } \\
\text { zones }\end{array}$ \\
\hline $1680-89$ & 100 & 100 & 100 & 100 & 100 \\
\hline 1690.99 & 75 & 83 & 80 & 82 & 79 \\
\hline $1700-09 \ldots$ & 89 & 67 & 57 & 63 & 75 \\
\hline $1710-19$ & 113 & 41 & 54 & 47 & 78 \\
\hline $1720-29 \ldots$ & 126 & 65 & 38 & 53 & 88 \\
\hline $1730-39 \ldots$ & 158 & 80 & 38 & 61 & 107 \\
\hline $1740-49$ & 208 & 57 & 34 & 47 & 123 \\
\hline $1750-59 \ldots \ldots \ldots \ldots \ldots \ldots \ldots$ & 245 & 61 & 44 & 53 & 144 \\
\hline $1760-69 \ldots \ldots \ldots \ldots \ldots \ldots \ldots \ldots \ldots \ldots$ & 246 & 85 & 50 & 70 & 153 \\
\hline $1770-79$ & 343 & 87 & 92 & 89 & 209 \\
\hline $1780-89 \ldots \ldots \ldots \ldots \ldots \ldots \ldots \ldots$ & 623 & 186 & 103 & 149 & 373 \\
\hline $1790-99 \ldots \ldots \ldots \ldots \ldots \ldots \ldots$ & 943 & 171 & 119 & 148 & 524 \\
\hline $1800-09 \ldots \ldots \ldots \ldots \ldots \ldots \ldots \ldots$ & 1.335 & 188 & 141 & 167 & 719 \\
\hline
\end{tabular}

SourcE: TePaske and Klein (1982b; 1986, 1988).

Mexico in contrast never looked back. It had a small boom in the 1720 s to 1750 s period, another pause in the 1760 s, though the economy was at a higher level of output than in the previous 17 th century peak. This mid-18th century pause was followed by the greatest period of sustained growth in the economy, which probably lasted from the late 1760 s until the early 1790 s. There then seemed to have occurred another levelling of output, if not actual decline, in the late 1790 s and early 1800 s. 
Tax revenue data also gives us some reasonable ideas about Spanish Royal fiscal policy as related to its American colonies. It seems that the Crown tried throughout most of the period not to burden the crucial mining sector with taxes which would cripple its ability to produce. The big producing zones of Mexico had their taxes reduced in the 17 th century, while the poorer zones of Alto Peru were slow to receive this support. Thus mining taxes were a much lower ratio of total revenues in Mexico than they were in Charcas. But once the Crown decided to support Alto Peruvian growth, then the relative importance of mine income declined here as well.

The rapid growth of tribute income in all three colonies was impressive and clearly reflected the growth of the Indian peasant population in America, which by the late 17 th century had finally recovered from the disastrous initial shock of contact with hitherto unknown European diseases. But however important such revenues became in Mexico, they never surpassed the other major categories of funds. In the relatively weaker economies of the two Perus, however, this regressive tax income by the end of the colonial period became the single most important source of government revenue in the two colonies.

There finally remains in terms of income, the special development within Mexico of the new war-related taxes and exactions which produced such enormous sums for the royal coffers in the post- 1780 period. Why the Crown concentrated its efforts exclusively on Mexico would appear to be based on the reality of Mexico as the single source of royal «profits» - i.e. remittances of specie from the royal treasury. This special taxation creates two problems. The first is its effect on the masking of actual economic conditions because of this sudden taxation of individual and institutional savings, which was in effect, a tax on the local capital market. Thus special higher taxes and loans were temporarily masking what appears to be the beginnings of a cycle of depression. This should have negatively affected consumption taxes, which does not seem to have been the case. Could this mean that the late 18th century boom created enough savings that these new royal taxes on capital did not diminish private consumption, even as actual output in mining, trade and agriculture declined? Could this be due to the very strong showing of the economy in the 1770-1799 period which created a wellspring of demand that even excessive taxation could not dampen? From the evidence at hand it is difficult to prove the case one way or the other. It is therefore difficult to know if this was a suicidal policy of a desperate metropolitan government willing to sacrifice its colonies in its concerns for European interests, or was this a sophisticated elite which in the crisis of European war was finally and effectively able to tax hitherto unexploited capital resources without really destroying the colonial 
economy upon which it depended. Some support for the latter hypothesis, is seen in the fact that the Crown did not attempt such monumental new tax extractions in either of the other two colonies.

How much did the Crown actually extract from this complex tax structure is another interesting finding from these treasury records. There is little question that Peru, which had stopped remitting monies to Spain after the 1740s was barely holding its own in terms of paying for local government and defense from the incomes it received and could afford little beyond this. Alto Peru on the other hand, was able to send large quantities of «excess» revenues outside its frontiers. Unfortunately for the Crown all of this money had to be directed to the maintenance of the new viceroyalty of Buenos Aires, which in turn could afford to send no serious quantities of «excess» revenues to Spain. Only Mexico could be relied upon to send massive financial support direct to the Madrid coffers. From the tax revenue data from Spain as well as these two viceroyalties one can in fact get a rough idea of how much money was transferred from Mexico (the only really surplus producer of revenues in all of America) to Spain. The answer is rather a lot. Given the very heavy costs of maintaining a defensive fortified frontier in the north and the Caribbean, of subsidizing most of the economies of the Spanish islands ${ }^{22}$, and of maintaining a major bureaucracy and military presence within the viceroyalty provinces themselves, it is amazing just how much the Crown was able to ship home ${ }^{23}$. Thus Humboldt estimated that the Crown in the period from 1796 to 1801 shipped on average 8 to 9 million pesos per annum in its own name to Spain ${ }^{24}$. While this represented only some $15 \%$ of total royal revenues from all sources, which in the six year period averaged 56.6 million pesos, this total was still impressive. These 8-9 million New Spain pesos of surplus royal revenues represented well over a third of the value of total silver and gold exports from the viceroyalty, and made up well over $3 / 4$ of Indies income coming to Spain in that period and was then clearly the largest single source of royal revenues from the New World ${ }^{25}$.

22 The so-called situado, or subsidy, to American and Asian provinces cost the viceroyalty treasury at its maximum some 3.6 million pesos in the $1780 \mathrm{~s}$, with 1.8 million of that sum going to Cuba. Humboldt (1811), V, p. 32.

${ }_{23}$ Some 10.5 million pesos on average went for internal administration and defense with the viceroyalty, Humboldt (1811), V. p. 26.

24 Humboldt (1811), IV, pp. 451-52.

${ }_{25}$ Throughout this essay I have stressed the term ssurplus» revenues, rather than use the term «net» income. Given the non-annual nature of royal expenditures and the complex pattern of inter-ramo transfers on the deber side of the ledger, it is difficult to see how such an annual «net» estimate could be generated despite a recent attempt to do so by Pérez Herrero (1991). 
Even at the level of gross revenues, the 48.2 million pesos generated by the royal treasury of New Spain in the 1790s was impressive by the Crown's own standards. From a population of 6 million persons, it represented a per capita tax of approximately 8 pesos per person. In the same period, the Crown grossed almost 50.2 million pesos from a metropolitan population of 10.5 million Spaniards. This meant that the richest colonials were paying over one and a half times the 4.8 pesos per capita paid by the inhabitants of the metropolis ${ }^{26}$.

The other expenditure patterns show relatively little surprises, especially in the light of my earlier studies of the Spanish metropolitan expenditures ${ }^{27}$. As in Spain itself, the major category of expenses was that of war, with little left over for social overhead expenditures. The actual administration of the colonial government was rather a small part of the Crown's expenditures, usually representing less than $10 \%$ of total expenditures. Thus in the decade of the 1750 s, when war costs absorbed $41 \%$ of the combined 16.3 million royal expenditures of the three colonies, administrative costs for these zones was but $7 \% 28$. By the $1780 \mathrm{~s}$, administrative costs were approximately the same in total volume as they were thirty years before. But as expenditures now totalled 39.4 million pesos for the three colonies, its relative importance declined to but $4 \%$. The only surprising result here is the consistently lower administrative costs of Mexico compared to the other two zones until the very end of the colonial period. War expenditures on the other hand had surpassed even the growth in total disbursements, and now accounted for $47 \%$ of this larger sum. Though shipments of «excess» funds outside America had risen from 1.8 to 2.7 million in this period, this growth was less than total expenditure increases and thus actually declined in relative importance in this period from $11 \%$ to just $7 \%$ of the total for these three colonies. Moreover, even as far as the Mexican surpluses were concerned, over half, or some 7.9 million pesos a 8 were spent in America, versus 6.0 million pesos sent to Spain. Of the surplus spent in America, some 5 million pesos went for subsidies to help to sustain the economies of the Caribbean islands, the frontier provinces along the Pacific and Atlantic coasts, and the famous northern mission frontier.

26 Barbier and Klein (1981), table 1. For the estimate of metropolitan Spain's population in the 1790 s, see Nadal (1973), p. 16.

27 Barbier and Klein (1981).

28 It should be noted, that while administrative cost in the three major colonies were included in the administration expenses category, the administration costs for the colonies which received subsidies from these three zones, were included in the war expenditures. Thus for America as a whole, administrative expenses were probably another $5 \%$ to $10 \%$ higher than the averages for the two Perus and Mexico. 
Finally, it is quite obvious that in America as well as in Spain the Atlantic wars of the late 18th and early 19th century were fatal for the economy. The ill conceived and poorly financed participation of Spain in these wars, especially the two against England, clearly was the major factor ushering in a new crisis in the Spanish American economies in the early 19th century, a crisis more severe than that of the late 17 th century. Moreover this was an economic crisis which now affected New Spain as profoundly as it did the two Andean colonies.

\section{BIBLIOGRAPHY}

BAKEWEll, Peter J. (1975): «Registered Silver Production in Potosi, 1550-1735», Jabrbuck für geschicte von staat, wirtschaft und gesellschaft Lateinamerikas, 12.

(1984): "Mining in colonial Spanish America», in Leslie Bethell, ed., Cambridge History of Latin America, Cambridge: Cambridge University Press, vol. II.

BARBIER, Jacques and Herbert S. KLEIN (1981): «Revolutionary Wars and Public Finances: The Madrid Treasury, 1784-1807», Journal of Economic History, XLI.

- (1986): «Las Prioridades de un rey ilustrado: el gasto público bajo el reinado Carlos III, 1760-1785", Revista de Historia Económica, III:3.

Bauzon, Leslie (1970): «Deficit Government Mexico and the Philippines 'Situado' (1606-1804)m, Ph. D. Thesis, Duke University.

Coatsworth, John H. (1978): «Obstacles to Economic Growth in Nineteenth Century Mexico", American Historical Review, 83, 1.

FisHER, John (1977): Minas y mineros en el Perú colonial 1776-1824, Lima, Instituto de Estudios Peruanos.

FonSECA, Fabian and Carlos de URRUTIA (1845-1853): Historia general de Real Hacienda, 6 vols., México, V. G. Torres.

GaRnER, Richard L. (1980): «Silver Production and Entrepreneurial Structure in 18th century Mexico", Jabrbuck fur Geschicbte von staat, wirtschaft und gesellschaft Lateinamerikas, 17.

HamnetT, Brian R. (1969): «The Appropriation of Mexican Church Wealth by the Spanish Bourbon Government: The 'Consolidation de Vales Reales', 1805-1809", Journal of Latin American Studies, I, 2.

Hernandez Palomo, José Jesús (1979): La renta de pulque en Nueva España, 1663-1810, Sevilla, Escuela de Estudios Hispanoamericanos.

HumboldT, Alexander (1811): Essai politique sur le royaume de la Nouvelle-Espagne, 6 vols., Paris, F. Schoell.

KLEIN, Herbert S. (1973): «Structure and Profitability of Royal Finances in the Viceroyalty of the Rio de la Plata in 1790m, Hispanic American Historical Review, 53:3. (1973a): «Las finanzas del virreinato del Río de la Plata en 1790», Desarrollo Económico, 50.

- (1985): «La economía de la Nueva España, 1680-1809: un análisis a partir de las cajas reales», Historia Mexicana, 34:4. 
(1991): «Las economías de México y Perú en el siglo XviIm, in Heraclio Bonilla, ed., El sistema colonial en la América Española, Barcelona: Editorial Crítica.

(1993): «Historia fiscal colonial: resultados y perspectivas», Historia Mexicana forthcoming.

— and Jacques BarbIER (1988): «Recent Trends in the Study of Spanish American Colonial Public Finance», Latin American Research Review, XXIII, 1.

- and Stanley ENGERMAN (1992): «Métodos y significados en la historia de preciosm, in Lyman Johnson and Enrique Tandeter, eds., Economías coloniales. Precios y salarios en América Latina, siglo XVIII, México: Fondo de Cultura Económica, pp. 17-30.

LAVRIN, Asuncion (1973): «The Execution of the Law of Consolidation in New Spain: Economic Aims and Results», Hispanic American Historical Review, 53, 1.

MaRICHAL, Carlos (1990): «Las guerras imperiales y los préstamos novohispanos, 1781 . 1804», Historia Mexicana, 39, 156.

Morun, Claude (1979): Michoacan en la Nueva España del siglo xvml, México, Fondo de Cultura Económica.

NADAL, Jordi (1973): La población española (siglos XVI a XX), Barcelona, Ariel.

O'Phelan Godoy, Scarlett (1986): «Las reformas fiscales Borbónicas y su impacto en la sociedad colonial del Bajo y Alto Perü, in Nils Jacobsen and Hans Jürgen Puhle, eds., The Economics of Mexico and Peru During the Late Colonial Period, 1760-1810, Berlin: Colloquim Verlag.

Pérez Herrero (1988): Plata y libranzas. La articulación comercial del México borbónico, México, El Colegio de México.

- (1991): «Los beneficiarios del reformismo borbónico: metrópoli versus élites novohispanas», Historia Mexicana, XLI:2.

SIERRA, Lamberto de (1808/1971): «Manifiesto» de la plata extraida del cerro de Potosi, 1556-1800, 1808 nss, printed; Buenos Aires: Academia Nacional de Historia.

SLICHER VAN BATH, B. H. (1989): Real Hacienda y economía en Hispanoamérica, 1541-1820, Amsterdam: EDLA.

SOETBEER, Adolf (1879): Edelmetall-Produktion und wertbverbaltniss zwiscben Gold und Silber, Gotha, J. Perthes.

TEPASKe, John J. (1982): «The Fiscal Structure of Upper Peru and the Financing of Empire», in Karen Spalding, ed., Essays in the Political, Economic and Social History of Colonial Latin America, Newark, Delaware, 1982.

- (1983): «New World Silver, Castile and the Far East (1590-1750)", in John F. Richards, ed., Precious metals in the later medieval and early modern worlds, Durham, N.C., n.p. 1983.

- (1985): «Economic Cycles in New Spain in the Eighteenth Century: The View from the Public Sector», in Richard Gardner and William B. Taylor, eds., Iberian Colonies, New World Societies: Essays in Memory of Charles Gibson, privately printed.

- (1986): «General Tendencies and Secular Trends in the Economies of Mexico and Peru, 1750-1810: The View from the Cajas of Mexico and Lima», in Nils Jacobsen and Hans Jürgen Puhle, eds., The Economics of Mexico and Peru during the Late Colonial Period, 1760-1810, Berlin: Colloquium Verlag.

(1987): «Bullion Production in Mexico and Peru, 1581-1810», Unpublished ms. (1991a): «La crisis financiera del virreinato de Nueva España a fines de la colo. nia», Secuencia, vol. 19 (enero-abril). 
- (1991b): «The Records of the King's Countinghouse: Problems and Pitfalls», Latin American Economic History Newsletter, no. 1 (december).

TePaske, John J. and Herbert S. KLEIN (1981): «The Seventeenth Century Crisis in New Spain: Myth or Reality", Past and Present, 90.

- (1982a): «Rejoinder», Past and Present, 97.

- (1982b): Royal Treasuries of the Spanish Empire in America, 3 vols., Durham, Duke University Press.

- (1986, 1988): Ingresos e egresos de la Real Hacienda en Nueva España, 2 vols., México, Instituto Nacional de Antropologia e Historia.

TORD, Javier and Carlos LAzo (1981): Hacienda, comercio, fiscalidad y lucbas coloniales (Perú colonial), Lima, Biblioteca Peruana de Historia, Economia y Sociedad. 